\title{
The Impact of Forestry on The Economy of The State of Azad Jammu and Kashmir
}

\author{
Nasim Akhter, Assistant Professor, \\ Department of Economics, Mirpur University of Science and Technology \\ Mirpur Azad Kashmir. \\ Dr.Sabahat Akram, PhD
}

Director Planning \& Development, Chairperson Department of Economics.

University of Management Sciences \& Information Technology, Kotli, AJ\&K.

\section{Dr. Bashir Ahmed Khilji, Professor. HOD of Economics \\ Preston University Kohat, Islamabad Campus \\ Shahid Hussain, Assistant Professor \\ Director Finance, University of Management Sciences \& Information Technology Kotli,AJ\&K.}

doi: 10.19044/esj.2016.v12n28p459 URL:http://dx.doi.org/10.19044/esj.2016.v12n28p459

\begin{abstract}
In this paper a study was carried out to assess the contribution and impact of forestry resource on the economy of the State of Azad Jammu \& Kashmir, as $42 \%$ of the total area is covered by forests. To conduct the study both secondary and primary data was used. Secondary data was collected from different public sector concerned departments. Primary data was collected through a comprehensive questionnaire from 212 selected respondents by using convenience sampling of 3 Forest Divisions which were $16 \%$ of total targeted population. Multiple Regression Model was applied by using last twenty years secondary data of ten sectors of the economy. The value indicates goodness of fit of the model. The results show that forestry resources are an important contributor to the state's National Income. The study recommends concerted efforts and integrated policy making to conserve the fragile eco system of mountainous areas like AJK. The primary and secondary data reveals that 16000 people are availing job opportunities through forestry resource.
\end{abstract}

Keywords: Sustainable Development, Wood based Employment opportunities, Women's Economic Empowerment 


\section{1-INTRODUCTION}

\subsection{Background}

No doubt Forests have always played a very crucial and significant role in shaping societies and diversifying livelihood options and looked at as nature's endowment that fulfills human needs for timber, firewood and fodder medicinal plants, watershed protection, soil formation and conservation, climate improvement and biodiversity conservation, refuge and shelter for a variety of organisms. Forests also contribute to the economy not only in the form of net revenue by selling forest wood but also provide job opportunities to large number of people. . Pakistan has 4.01 million hectares covered by forests and is providing job opportunities to half a million people, providing 363 thousand cubic meters of timber which constitute as one-third of the nation's energy needs. Forests and rangelands support about 30 million herds of livestock, which contributes more than U.S\$ 400 million to Pakistan's annual export earnings. Forestry sector plays an important role in soil conservation, regulates flow of water for irrigation and power generation, reduction of sedimentation in water conveyances and reservoirs, employment and maintenance of ecological balance.

Forestry and forest products form an important component of local livelihoods and also income for the State of Azad Jammu \& Kashmir. These forests are a major source for construction timber that is used locally and shipped out of Azad Jammu \& Kashmir to Pakistan. The overall situation for forests in Azad Jammu \& Kashmir, however, is grim as it is fast losing its forest cover. There are 3.596 million persons who live in the State of Azad Jammu and Kashmir's territory and. Over 90\% of the people depend largely upon these forests for their subsistence. At present $42.6 \%$ area of state is under the control of forest department but it is a legal ownership only. The potential commercial forest area estimated at $20 \%$ of the total forest area (FAO, 1997). Rest of the area is snow covered peaks, barren rocks, glaciers, streams and pasture lands. Besides wood products the forests have other life supporting role in residents lives, like water, environment, net revenue contribution to state, job opportunity, grazing, wildlife, fish, medicinal plants, culture, spiritual values, tourism, education and so on which compel us to manage this precious resource with great care.

Scientific management and perpetuation of tree covered watersheds of The State of Azad Jammu \& Kashmir is important not only for the people of the State but also for the millions of people living down below in the Indus valley. Maintenance of these watersheds means clean water for human consumption, agriculture, power generation and economic uplift of the people of Punjab and Sindh. Total Geographical Area of the State of Azad Jammu \& Kashmir is 3.286 million acres. 
Table 1.1 General Distribution of Land Utilization In The State of Azad Jammu \& Kashmir.

\begin{tabular}{|c|c|c|c|}
\hline S.\# & Land Utilization & Area( million Acre) & \%Age \\
\hline 1 & Area under forest & 1.400 & 42.6 \\
\hline 2 & Area under cultivation & 0.427 & 13 \\
\hline 3 & Area under cultivable waste & 0.080 & 2.4 \\
\hline 4 & Area under uncultivable waste & 1.379 & 42 \\
\hline & Total & 3.286 & 100 \\
\hline
\end{tabular}

Source: Planning and Development Department Muzaffarabad.

There are different types of vegetation in the of State of Azad Jammu and Kashmir which include Dry Subtropical Scrub Forests, Subtropical (Chir) Pine Forests, Moist Temperate Forests, Dry Temperate Forests, Sub Alpine Forests and Alpine Shrub and Pasture. Forests play a vital Role in the Economy of the State of Azad Jammu \& Kashmir which is evident as;

Average Rs. 1.00 billion net revenue is realized through the sale of timber per annum. (Forestry Statistic (2006, FD AJ\&K). By virtue of forest 3000 persons have secured employment opportunities on permanent basis through forest department and Azad Kashmir Logging and Sawmill Corporation. (Forestry Statistic (2006) FD AJ\&K) Temporary job opportunities for laborer residing in the state by carrying out forestry operation like logging, transportation of timber and by planting. Establishment of small enterprise wood based industries in Azad Jammu \& Kashmir is also source of income for locals and job opportunities for skilled laborers. Rs. 30.00 million incomes can be attributed to fishing.

Forests provide fuel wood \& timber wood to the local community. By forestry intervention of income generating activities family income is improved. Rural ladies' participation in income generating activities is made possible like kitchen gardening, encouragement of private forest nurseries rising, poultry farming, and honey bee keeping empowering the rural women.

\subsection{Objectives of the Study}

The main objectives of the proposed research are:

- To examine the role of forests in the economy of the state of Azad Jammu \& Kashmir.

- To find out the way in order to foster the sustainable development of renewable natural resources of the State for the maintenance and rehabilitation of its environmental and enhancement of the sustainable livelihood of its rural masses.

- To highlight effects of management techniques regarding Forest and Forest Land, Private Wood lots of the area as well. 
- To assess the impact of development works and provide some policy options workable for decision makers for better future planning and management.

\section{2-REVIEW OF LITRATURE}

Ciriacy et al. (1955) stated that individuals who used land in watershed areas may be compelled by economic considerations to adopt practices not in accord with the public interest in land are, in order to control erosion and retard flood flows, to keep certain steeply sloping areas of erosive soil in permanent cover of grass or trees. It may be of interests of society to preserve a forest cover on steep mountain sides, but persons with no alternative means of livelihoods may clear forests away in order to control and retard flood flows. Still if the users of such land are faced with a price situation in which income potential from serial production is greater than in either grassing or forestry, grain is likely to be produced with soil erosion and accelerated surface run off as by-products. Land use in the public interest is not necessarily also in the private interests of the individuals who use it.

Singh (1971) stated that people are the most important factor in a government watershed management. According to the study, the root cause of watershed degradation in most of the developing nations is ignorance and economic backwardness of people and their outmoded social systems. He reported that socio economic problem was further deteriorated by increasing population pressure and lack of alternative means of livelihoods. The problem was firstly aggravated by political situations. The destruction of forests by fire was due to ignorance caused deep rooted economic evils and belief of forest dweller that fire produce fresh flush of green grass, destroyed insects and wildlife harmful to cattle or even propitiate the rain gods in time of prolonged drought. What was particularly important in putting any of these ideas and reforms into effect was the consciousness that the new ideas were more acceptable to people when they came not from outsiders but from their own kind of people and especially those whom they grow up with and trust. According to him the most important factor in watershed management and resources development are local communities.Grant (1979) discussed the positive social benefits of forestry development and suggested that most exotic forestry development was not economically viable without social benefits. Social benefits include employment and income benefits to the local communities. Edmonds (1981) reported that Local councils have responded to the conflict between forestry and farming by blocking forestry under the District Planning Scheme (DPS). In 1981 an increasing number of District schemes were confining forestry to a 'conditional' use, imposing restrictions on its development or prohibiting it altogether. He examined 
those District Councils responses and concluded that these controls appear to be based on arbitrary judgments rather than substantial justification. There was a need for change in attitudes and institutional responses if New Zealand was to fully utilize their forestry potential. The study provided a good overview of reasons behind the farm-forestry conflict and a brief investigation of social and economic impacts predominantly dealing with local government responses to the conflict. Edmonds believes that policies should be flexible enough to allow both forestry and farming to occur.

Nuttall (1981) discussed that regarding forestry development most of the effects identified were the same as the impacts of any rural community. It was highlighted by the researcher that problems with forestry development; the Maori community doesn't have the expertise, finances etc. To develop forestry, but leasing the land for forestry resulted in alienation of the land for up to three generations. Often the Forestry development that has occurred has not met the long term needs of the people. Olsen (1981) reported that forestry has expanded at a fast rate since the 1970s. However, most planners' reactions have been negative or restrictive. It was examined that the attitudes of councilors and their ratepayer's to discover why forestry was supported in some cases and rejected in others. The attitudes fall into three headings; concerns over changes in land use, economic factors, and rural community effects. The researcher discussed the negative impacts of forestry and the positive benefits for the Community economically and socially. Chapman (1984) reported that Forestry was not a major industry in Otago and Southland, but had great potential as an area for future large afforestation. He briefly outlined the positive and perceived negative benefits of forestry that could occur if forestry went ahead. Local governments in those regions were keen to recognize the positive benefits of afforestation. So the study was made to identify and evaluate the opportunities for forestry to contribute to the regions' social and economic development.

Fletcher (1984) concluded that in recent years horticulture and forestry have become viable alternatives to pastoral farming in many areas of New Zealand. According to researcher, trend was expected to continue at the present rate into the next decade. Exotic Forestry, which was expected to increase in area of $30 \%$ to 1.3 million hectares by 1990 , could produce 20 $25 \%$ of their exports by the year 2000. Horticultural experts could be earning $\$ 1000$ million by 1990 , a four fold increase from 1982. He discussed the expansion of horticulture and forestry was most likely to impinge on existing pastoral land. The Land Use Capability (LUC) concept was used throughout the research as a land resource base for discussing land use trends. Social and economic factors were not discussed by the researcher. 
Daru and Tips (1985) have discussed the watershed management project in densely populated areas of central Java, Indonesia in terms of its achievements in combining activities to improve the physical, social and economic environment. They stated that without simultaneous, well planned action on these three essential components the projects' improvements can not be sustained by the farmers. They found that activities such as tree planting and maintenance, construction of soil erosion, control structures and training in agro-forestry type intensification techniques for land cultivation serve as a focus to induce farmers to participate. According to them the participation can be sustained in spite of initial decreasing net income, if increase in land productivity based on agro-forestry practices together with appropriate training programs organize and motivate the farmers. They suggested that in future watershed management programs should give more emphasis on the rural development planning aspects of agro-forestry techniques and on rural community organization.

NKI and NKWAIN (1987) conducted an economic and sociological analysis of mixed seed cropping in Menoua Division of Cameroon. They reported that the rural population of that area lived in compounds. Compounds were made up of several houses, belonging to the same family. Each farmer in this division has at least several hundred coffee trees. These trees were grown around the compounds. The data was collected from questionnaires distributed randomly to 165 families, supplemented selective interviews. Two mixed cropping system was found. A coffee based mixed cropping systems was practiced with other fruit trees and crop based mixed cropping system was followed further away from homesteads; several arable crops were inter- cropped. Coffee, maize, cocoyam, were the most important crops grown in Menoua under mixed cultivation. They studied that the farmers' income was inequitably distributed greater than $50 \%$ of them earning below 100000 CPA France, while the average income was about 170000 CPA France from 2.5 hectare of land. They further concluded that income distribution was highly related to land holding size.

Meister (1987) reported that the allocation of land between farming and forestry has been the cause of many conflicts. On the one hand there were those wanting a free market decide' approach, while on the other hand there were people who see the need for planning to achieve objectives other than economic. These two approaches were discussed in the light of historic developments and current government policies. The paper concluded that while there was room for market forces in the rural land market, control was still required in some cases. It was discussed that there should be less antagonism and a better opportunity for using land for the most appropriate purpose. That was being facilitated by the changing attitudes of foresters, farmers and local government councilors. He concluded that how to deal 
with socio-economic and environmental impacts. The article summarized social and economic impacts. He suggested that the negative impacts of forestry were primarily in the early years of the forestry boom, when forestry companies showed little concern for impact assessment. As a result the impacts created the negative attitudes which created strong laws against the expansion of forestry. He reported that negative impacts of forestry development were decreased and they were being planned for. As a result, rural attitudes need to change as positive benefits become more prevalent, and more forestry welcomed.

Allen et al. (1990) discussed the magnitude and duration of response of southern pine forests to operations silvicultural treatments, including site preparation, drainage, bedding, weed control, thinning, and fertilization were reviewed by the researchers. The information for making sericultural prescriptions in the southeastern U.S. had been developed largely from empirical trials. Sericultural research provided only a rudimentary understanding of how water and nutrient availability was altered through

\section{3-Material and Methods}

\subsection{Method of Data Collection}

For the study "The Impact of Forestry on the economy of the State of Azad Jammu\& Kashmir" Primary and Secondary Data was collected and used extensively to assess the revenue contribution of forestry resource towards Azad Jammu \& Kashmir' economy. . Secondary data was collected from Chief Conservator Office, Divisional Forest Offices from ten forests Division, Finance Department ,The Office of Deputy Secretary, Finance Department , Planning and Development Department , and AKLASC(azad kashmir Logging and Sawing corporation were approached. To collect Primary data a well designed questionnaire was developed. This data was collected to analyze the job opportunities provided by forestry resource other than permanent employment. The 16\% (212) of total wood-based units (1261) were selected. Questionnaire-cum interview technique was pre-tested. The respondents were interviewed individually in Urdu \& local Paharri language .All the information against each question was recorded in the field.

\subsection{Data Compilation and Analysis}

All the data (Secondary and Primary) collected, was transferred on a tally sheet for compilation. For the revenue contribution of forestry resource to the economy averages and percentages were calculated by using simple statistical methods for interpretation, discussion, drawing conclusion and making pertinent recommendations. To calculate \%age sharing of Forestry resource towards economy the following method was used 
Forestry Percentage $=\frac{Y_{F}}{Y_{A J \& K}} \times 100$

Where,

$\mathrm{Y}_{\mathrm{F}}=$ forestry sector

$\mathrm{Y}_{\mathrm{AJ} \& \mathrm{~K}}=$ total income of AJ\&K economy

To make regression analysis twenty years revenue contribution by 22-sectors of the State of AJ\&K economy were collected and multiple regression models were applied.

At first stage 22-sectors (following table) were considered as independent variables and Economy is considered as Dependent Variables

Table 3.1. List of Independent Variables for Regression Model.

\begin{tabular}{|c|c|c|c|}
\hline \multicolumn{1}{|l|}{ Sectors } & $\begin{array}{l}\text { Independent } \\
\text { Variable }\end{array}$ & \multicolumn{1}{l|}{ Sectors } & $\begin{array}{l}\text { Independent } \\
\text { Variable }\end{array}$ \\
\hline Provisional Excise & $\mathrm{X}_{1}$ & Industries, Labor \& Minerals & $\mathrm{X}_{12}$ \\
\hline Land Rev. \& settlement & $\mathrm{X}_{2}$ & Seri culture & $\mathrm{X}_{13}$ \\
\hline Forests & $\mathrm{X}_{3}$ & Communication \& works & $\mathrm{X}_{14}$ \\
\hline Administration of Justice & $\mathrm{X}_{4}$ & Electricity & $\mathrm{X}_{15}$ \\
\hline Jail & $\mathrm{X}_{5}$ & Printing press & $\mathrm{X}_{16}$ \\
\hline Home (Police) & $\mathrm{X}_{6}$ & Armed services board & $\mathrm{X}_{17}$ \\
\hline Education & $\mathrm{X}_{7}$ & Religious Affairs & $\mathrm{X}_{18}$ \\
\hline Health & $\mathrm{X}_{8}$ & Food & $\mathrm{X}_{19}$ \\
\hline Agriculture & $\mathrm{X}_{9}$ & Stamp & $\mathrm{X}_{20}$ \\
\hline Animal Husbandry & $\mathrm{X}_{10}$ & Miscellaneous & $\mathrm{X}_{21}$ \\
\hline Co-operative & $\mathrm{X}_{11}$ & Registration & $\mathrm{X}_{22}$ \\
\hline
\end{tabular}

At $2^{\text {nd }}$ stage 10 major departments were selected for regression analysis because it is rule for regression that Nos. of observations should be greater than Nos. of parameters 10 Departments were selected as, $X_{1}$ (Provisional excise), $\mathrm{X}_{2}$ (Land Revenue), $\mathrm{X}_{3}$ (Forest), $\mathrm{X}_{6}$ (Police), $\mathrm{X}_{7}$ (Education), $\mathrm{X}_{8} \quad$ (Health, ) $\quad \mathrm{X}_{9}$ (Agriculture), $\mathrm{X}_{12}$ (Industry) $\mathrm{X}_{14}$ (Communication and Works), $\mathrm{X}_{15}$ (Electricity.

- $\quad \mathrm{Y}=$ Economy of the State of AJ\&K was taken as dependent variable.

Table 3.2. List of Major Ten Independent Variables for Multiple Regression.

\begin{tabular}{|c|l|c|l|}
\hline Sectors & $\begin{array}{l}\text { Independent } \\
\text { Variables }\end{array}$ & Sectors & $\begin{array}{l}\text { Independent } \\
\text { Variables }\end{array}$ \\
\hline Provisional Excise & $\mathrm{X}_{1}$ & Health & $\mathrm{X}_{8}$ \\
\hline Land Rev. \& settlement & $\mathrm{X}_{2}$ & Agriculture & $\mathrm{X}_{9}$ \\
\hline Forests & $\mathrm{X}_{3}$ & $\begin{array}{c}\text { Industries, Labor \& } \\
\text { Minerals }\end{array}$ & $\mathrm{X}_{12}$ \\
\hline Home (Police) & $\mathrm{X}_{6}$ & Communication \& works & $\mathrm{X}_{14}$ \\
\hline Education & $\mathrm{X}_{7}$ & Electricity & $\mathrm{X}_{15}$ \\
\hline
\end{tabular}

\subsection{The Regression}

Regression analysis is concerned with the study of the dependence of one variable, the dependent variable, on one or more other variables, the 
explanatory variables, with a view to estimating and/or predicting the (population) mean or average value of the former in terms of the known or fixed (in repeated sampling) values of the later. After compilation the data multiple regression was applied as;

Regression Analysis: $\mathrm{Y}$ versus $\mathrm{X}_{1}, \mathrm{X}_{2}, \mathrm{X}_{3}, \mathrm{X}_{6}, \mathrm{X}_{7}, \mathrm{X}_{8}, \mathrm{X}_{9}, \mathrm{X}_{14}, \mathrm{X}_{15}$

\section{4-EMPIRICAL ANALYSIS}

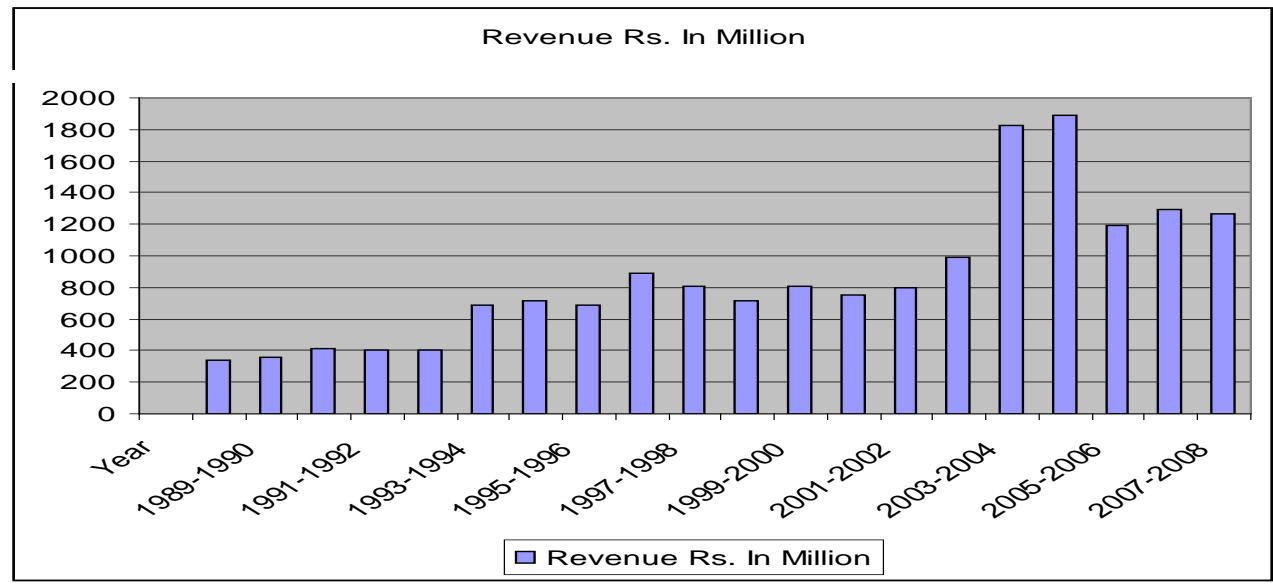

Figure 4.1. Twenty Years revenue Realization from Forestry Resource (1988-89to2007-08)

Figure shows twenty years revenue contribution from forestry resource. Upward \& downward trends indicate different year's contribution that when demand of wood products and timber in market is high its prices raise up which mean more revenue and vice versa

\section{The regression equation is}

Total $=236+1.55$ Provisional Excise +0.843 Land Rev. \& settlement +0.567 Forests -6.6 Home (Police) + 6.6 Education - 6.6 Agriculture +0.426 Communication \& works +1.20 Electricity

Table 4.1. Regression Results of Predictors Affecting the Economy of AJ\&K State in

Last Twenty Years

\begin{tabular}{|lc|r|r|r|r|}
\hline \multicolumn{1}{|c|}{ Predictor } & & \multicolumn{1}{c|}{$\begin{array}{c}\boldsymbol{\beta} \\
\text { Coeficient }\end{array}$} & $\begin{array}{c}\text { Standardized } \boldsymbol{\beta} \\
\text { Coefficient }\end{array}$ & \multicolumn{1}{c|}{ T } & P \\
\hline \multicolumn{1}{|c|}{ Constant } & & 236.0 & 456.0 & 0.52 & 0.616 \\
\hline Provisional Excise & $(\mathrm{X} 1)$ & 1.5503 & 0.6249 & 2.48 & 0.090 \\
\hline Land Rev. \& settlement & $(\mathrm{X} 2)$ & 0.8434 & 0.6484 & 1.30 & 0.222 \\
\hline Forests & $(\mathrm{X} 3)$ & 0.5669 & 0.3016 & 1.88 & 0.032 \\
\hline Home (Police) & $(\mathrm{X} 6)$ & -6.62 & 16.95 & -0.39 & 0.705 \\
\hline Education & $(\mathrm{X} 7)$ & -6.57 & -0.15 & 0.43 & 0.676 \\
\hline Agriculture & $(\mathrm{X} 9)$ & -6.62 & -0.18 & -0.07 & 0.942 \\
\hline Communication \& works & $(\mathrm{X} 14)$ & 0.42 & 0.32 & 0.47 & 0.651 \\
\hline Electricity & $(\mathrm{X} 15)$ & 0.19 & 0.10 & 2.59 & 0.027 \\
\hline
\end{tabular}


Table 4.1 indicates that X15 (Electricity) is significant at 0.027 level of significance, X3 (Forest) is significant at 0.032 level of significance, X1 (Provisional Excise) is significant at 0.090 level of significance, X2 (Land Revenue\& Settlement)) is significant at 0.222 level of significance, X14 (Communication \& Works) is significant at 0.651 level of significance,

Table 4.1 results of the estimation of regression of basic equation. It can be seen from the table 4.1 that almost all predictor variables (sectors of economy) have positive and significant coefficients. The more important are the ones having higher $\beta$ coefficients that are excise \& Taxation, land revenue and forests. And the magnitude of coefficients is negative for some social sectors like education and food security where government spends more.it was evident that these were prominent sectors of economy.

Table 4.2Results of Diagnostic Tests

\begin{tabular}{|l|c|}
\hline Diagnostic Tests & \\
\hline Adjusted R2 & .98 \\
\hline F \& F Change & 277 \\
\hline Significant F change & .000 \\
\hline VIF (Average) & 1.4 \\
\hline Durban-Watson Test & 2.17 \\
\hline
\end{tabular}

Table 4.2 presents different diagnostic tests which were carried out to check the validity and reliability of the variables and the data. Large F ratios prove model fit and sig. F change values establish fit of the regression model and Durban Watson statistic fulfills the assumption of independent errors.

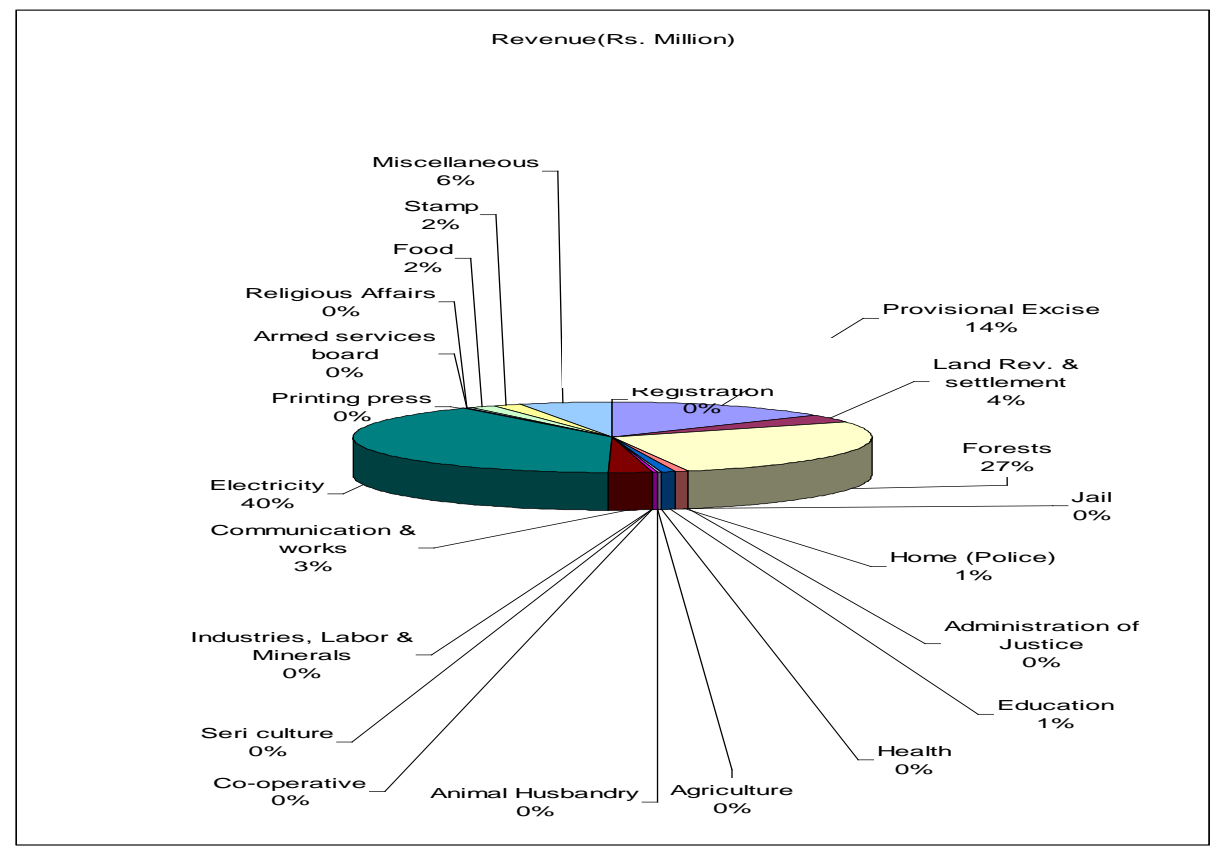

Figure 4.2Percentage sharing by the all sectors of the economy (1988-89 to 2007-08) 
Figure 4.2 shows Percentage sharing by different sectors of the economy of AJ\&K state. The Figure shows that forestry resource is $2^{\text {nd }}$ largest revenue contributing resource to the economy of the state.

\section{5- FINDINGS, CONCLUSION AND RECOMMENDATIONS}

The Multiple Regression model applied indicated goodness of fit of the model and it explains $\mathbf{9 8 \%}$ variation. The overall significant of fitted regression model indicated that model is significant at $\mathbf{0 . 0 0 0}$ level of significance. The last twenty years 'Data shows that $\mathbf{2 7 . 4 5} \%$ on an average of total national income is contributed by the forestry resource.

One main impact of forestry on the economy of the State of AJ\&K is provision of jobs to thousands of people. Some of them are permanent employees of Forest Department government of the State of AJ\&K and AKLAS some are on casual basis. Thousands of people are engaged with wood based units. Forestry resource is providing direct employment opportunity to 16001 people.

The impact of forestry is significant as compared to other sectors. It depicts clearly that the forestry is the second largest revenue contributing sector of the economy as by contributing $\mathbf{2 7 . 4 5 \%}$ of the National Income of the State. Besides this, Forestry resource is providing direct employment opportunities to $\mathbf{1 6 0 0 1}$ People. If forestry resource is managed properly by overcoming challenges, threats and issues it may contribute even more than the concluded results.

\subsection{Recommendations}

The new millennium poses a number of challenges for the forestry professionals in the country. The significant inventions of last century like computer, remote sensing, satellite imageries, Geographic information system and rapid progress in the field of information technology had entirely changed the management of natural resources. In the field of forestry itself a number of new areas like landscape ecology, Eco-system management, biodiversity conservation, environmental improvement, community forestry, and agro-forestry and farm forestry had emerged. The foresters in the other parts of the world particularly in the developed countries had benefited a lot from new technologies and research within the forestry disciplines.

For future better management of the state of AJ\&K's natural resources, local communities should have clear rights and control over the resources. Communities must be trained to enable them to assume their rights and obligations in a good way. Natural resources related enterprises development and marketing links be encouraged to ensure sustainability. A serious effort should be made to involve the women and to respond to their needs in a culturally accepted way. 
- The population planning agencies in Government and NGOs shall formulate and implement culturally appropriate strategies and action plans of invigorating population planning programs in critical ecosystems such as the wooded mountain environments.

- As their contribution to the rehabilitation of environment, all the concerned government agencies, international and national firms shall extend the supply of piped natural gas, LPG, solar energy and micro-hide power to the wooded mountains.

- In the poverty alleviation and other development programs, high priority shall be given to integrated land use projects for the sustainable rehabilitation of renewable natural resources with participatory approach.

- Through timber harvesting; and fuel wood collection; also for the sustainable utilization of non-wood forest products such as medicinal plants, mushrooms, wild honey, gums, wild fruits and nuts through participatory involvement of local communities as income generating activities for the rural masses should be initiated

- Concept of ecosystem should be adopted to encourage, conservation and restoration of fragile eco system.

- Since the over - exploitation of natural forests for timber, fuel and fodder is the main cause of the ecological destruction of the State of AJ\&K territory. Government shall encourage and assist the forest department in its programs of growing forest trees and fodders etc on farmlands with the participation of their owner.

- A systematic, periodic, external evaluation system should be adopted to ensure the proper implementation of joint forest management initiatives.

- Improve house design to reduce timber need as well as make it more earthquake resistant.

- Ensure the valuation of goods and services from the forest ecosystems, payment for environmental services, reforestation /afforestation of public and private lands.

- Intensive soil conservation works in upland catchments to enhance the water capacity of water reservoirs.

- Watershed protection, management and social forestry involving women as development partner.

- Imitating and promoting Joint Forest Management are highly needed.

- Control overgrazing of pasture lands they will rehabilitate naturally.

- Awareness building and social mobilization of a complex mix of local and nomadic users of the area.

- Many valuable medicinal plants and non-timber forest products grow in the rangelands of the area. As an alternative source of income, the local users 
should be encouraged to collect and sell some of these products. The program would help them to identify the most interesting species, to manage these resources in a sustainable way and to build appropriate market linkages.

\section{References:}

1. Allen, H.L., Dougherty, P.M. and Campbell, R.G. (1990). "Manipulation of water and nutrients - Practice and opportunity in Southern U.S. pine forests”. Forest Ecology and Management, 30 (14), 437-453.

2. Chapman, B.T. (1984). "Threats and Promise the Otago - Southland Forestry opportunities study”. Planning Quarterly, 76, 7-8.

3. Ciriacy Wantrup, SV. (1955). "Benefits cost analysis" Journal of Farm Economics USA, VOL.37.

4. Daru, R.D. and Tips W.E.J. (1985). "Farmers Participation and Socio Economic effects of Watershed Management Programme in central Java” Agro Forestry System, 3(3). 159-180.

5. Fletcher, J.R. (1984). "Pastoral land-horticulture and forestry as competing land uses”. New Zealand Agricultural Science, 18(3), 164167.

6. Grant, R.K.(1979). "Managing the regional impact of Forest Development Programmes”. New Zealand Journal of Forestry, 24 (1), 198-204.

7. Meister, A.D. (1987). "More market Planning, Forestry and farming". New Zealand Forestry, 32 (1), 28-31.

8. Nuttall, R.E. (1981). "The impact of Exotic Forestry on Maori Land in Northland”. New Zealand Journal of Forestry, 26 (1), 112-117.

9. NKI NkWAIN (1987). "A socio economic sociological analysis of Mixed Cropping in Me nona Division Cameroon”. Agro Forestry Abstract, 3(1).

10. Olsen, P.F. (1981). "Forestry-a diversification of rural income". People and Planning, 20, 9-10.

11. Olschewski, R., Benítez, P.C., de Koning, G.H.J., Schlichter, T.(2005). "How attractive are forest carbon sinks? Economic insights into supply and demand of Certified Emission Reductions". Journal of Forest Economics, 11( 2), 77-94.

12. Singh,G. (1971). "Watershed Organization and Socio-Economics factors, India”. FAO Guide (1977). 